\title{
Improving Student Learning Outcomes Using the Class IV Joyful Learning Method in Elementary School
}

\author{
Yulanti S. Mooduto ${ }^{1}$, Adinda Vrisca Musa ${ }^{1}$ \\ Email:yulanti13@gmail.com \\ ${ }^{1}$ Elementary School Teacher Education Study Program, Faculty of Teacher Training and \\ Education, University of Muhammadiyah Gorontalo, Indonesia
}

Received: May 7, 2021

Revised: June 9, 2021

Accepted: June 20, 2021

\begin{abstract}
The purpose of this research was to improve student learning outcomes by using the Joyful Learning Method in social studies subjects for class IV at SD Negeri 16 Paguyaman, Boalemo Regency. The results indicated the Joyful Learning method can improve student learning outcomes in social studies subjects. This is indicated by the results of student learning activities in the first cycle reaching an average percentage of $71.25 \%$ and in the second cycle an average of $85 \%$, with an increase of $13.75 \%$. Likewise, the learning outcomes of students produced with a mastery percentage of $61.91 \%$, with a $\operatorname{KKM} 75$, while the average value of students in the second cycle experienced an increase, with a completeness percentage of $80.95 \%$. The conclusion is the implementation of the Joyful Learning method can improve student learning outcomes in social studies subjects.
\end{abstract}

\section{Keywords: Joyful Learning Method, Learning Social Studies, Learning Outcome}

\section{Introduction}

Science is the key to the progress of a nation. Science is never separated from education and the role of educators. The task of educators is very noble, namely as agents of change, agents of change in fighting ignorance. The writer Taufik Ismail (Shadiq, 2011) says that educators are the spearhead of disseminating knowledge and one of the most important agents of change.

With regard to the process of education and learning, of course, you will be dealing with the main subject, namely students. Students are part of a major component in the practice of education and learning in elementary schools. The teaching and learning process must please both students and educators. There should be no tension in teaching, nor should learning bring fear. For this reason, according to Munif Chatib (2014) in his teacher's book, humans. Teachers or lecturers as educators must be able to choose a fun learning method. Furthermore, Hasib et al. (2021) argue that teacher's teaching strategy determines students performance in leanring.

For this reason, the main task of an educator is to teach students. The main problem faced and needs to be solved is what can and should be done, then how it should be done. Designing a 'fun' learning environment in elementary schools is essentially the same as when designing learning in general; material design, competency/objective design, method/strategy/technique design, evaluation design, it's just that attention to the psychological aspects of learning and the psychology of student development is taken into consideration at every step of learning, and the most dominant in the successful implementation of the learning design is the ability of educators in teaching.

From the results of pre-action research conducted through interviews with fourth grade teachers at SDN 16 Paguyaman, Boalemo Regency, it was explained that in teaching and learning activities he used the lecture method on social studies subjects, while the media used was 
limited to what was provided at school. Judging from these circumstances, the strategy method used is still not good. The monotonous social studies learning process does not involve students directly in learning, it can be seen that there are more teacher activities than students. After class observations, the students are known to be lazy and bored in learning social studies. The learning process has not used innovative methods. Few students actively ask or answer the teacher's questions.

Joyful learning is one of the appropriate alternative learning methods that can avoid student saturation in learning, students are directly involved as learning subjects so that they are always happy to learn and comfortable to linger in class. The principle of joyful learning is if students are happy and "learn to know" what they are learning for.

In simple terms, what is meant by student learning outcomes is the ability obtained by children after going through learning activities. Because learning itself is a process of someone trying to obtain a form of behavior change that is relatively permanent.

Gegne and Brings (in Husamah et al., 2018) learning outcomes as something that is obtained, obtained and liked after the learning process is usually indicated by grades or scores. Bloom (in Sudjana 2016) the classification of learning outcomes is broadly divided into three domains, namely the cognitive, affective and psychomotor domains. Hamalik (Yudha, 2018) states that learning outcomes will appear in every change in aspects: knowledge, understanding, habits, skills, appreciation, emotional, social relations, physical, ethical or character, and attitudes.

According to Carrol (Sudjana, 2011) in his book states that the learning outcomes achieved by students are influenced by five factors, namely: (1) student talent, (2) time available for learning, (3) time needed by students to explain the lesson, (4) teaching quality, (5) individual ability.

Social studies in a broad sense, namely the preparation of young people so that they have the knowledge, skills and values necessary for active participation in society. According to Samaadmadja, IPS is nothing but subjects or courses that study social life whose studies integrate the fields of social science and humanities. (in Siska, 2016). According to Kenworthy in the Ministry of Education and Culture (Susanto, 2014) there are three characteristics of social studies goals, namely: humanitarian education, civic education and intellectual education.

According to Susanto (2014) when viewed from the scope of the material, the field of social studies studies has the following characteristics; (a) Using a broad environmental approach; (b) using an integrated approach between similar subjects; (c) contains material concepts, social values, independence and cooperation; (d) able to motivate students to be active, creative, and innovative, and in accordance with the child's development; (e) able to improve students' thinking skills and broaden cultural horizons.

According to Asmani (2013) method means a path that must be passed or a way to do something or a procedure. Meanwhile, according to Sunhaji (Asmani, 2013) says that learning is an activity to transform learning materials to study subjects. So it can be concluded that the learning method is a path or way that is passed by educators to obtain learning objectives.

According to Salirawati (2018) Joyful learning comes from the word joyful which means fun, and learning which means learning. So, joyful learning means fun learning. Joyful learning is based on the principle of creating a class that is fun, not monotonous (Ardiyanti et al., 2021; Saragih, 2016), so that students are comfortable lingering in class, and keep away from boredom or boredom in learning. Because the learning atmosphere in joyful learning is fun, students will focus their full attention on learning so that the time on stake is high. E Mulyasa (Salirawati, 2018) According to the results of the study, high attention span has been shown to improve learning outcomes. 
In the implementation of joyful learning according to Djamarah (2010) there are four principles that are implemented, namely Experiencing, Interaction, Communication and Reflection. The principle of implementing Joyful learning, among others, according to Salirawati (2018); (1) Application of joyful learning through songs; (2) Application of joyful learning through games

According to Salirawati (2018) Joyful learning in its implementation uses a learning process that gives a happy impression by applying joyful learning through songs. One way to bring students to a pleasant atmosphere is to sing in response to the material or the application of joyful learning through games, playing puzzles.

The following are the steps for implementing joyful learning used in the study: (a) Students are divided into groups; each group consists of 5-6 students; (b) Using a special hat or a piece of paper that has been prepared for use in guessing; (c) Prepare several questions according to the number of participants in each group on a hat or piece of paper that will be worn by students; (d) The teacher determines the group that will appear (each group chooses one of them to be the word guesser guide). The teacher explains the rules of the game as follows; (1) The time used to answer each student's questions is 60 seconds; (2) The word guessing guide can only say: no if the answer is wrong, maybe if the answer is close to or almost right, and yes if the answer is correct.

(Azmin, 2016) The advantages and disadvantages of joyful learning-based methods include: (1) The advantages of the joyful learning-based method include; (a) Relaxing and fun learning atmosphere; (b) Stimulates creativity and activity; (c) More variety in delivering learning materials. (2) Lack of joyful learning-based methods; (a) The class will be very crowded and difficult to control; (b) Educators must have high creativity so that students do not get bored

\section{Methods}

The research was conducted in the fourth grade of SDN 16 Paguyaman, boalemo district. Especially for the fourth grade students. which amounted to 21 students, 11 female students, 10 male students in the 2020/2021 school year. This research is a classroom action research (CAR). The stages carried out in this CAR use a design developed by Suharsimi Arikunto who developed a cycle model into two cycles but if the two cycles have not reached the goal, then the next cycle can be continued. Data collection techniques in this study were through interviews, observation sheets of teacher and student activities during the implementation of learning, learning outcomes tests and documentation.

\section{Results and Discusssion}

The action in this study was carried out in two cycles. Each cycle consists of three meetings conducted in this study is the observation of the performance indicators in this study, namely; (a) The results of observing the activities of educators; (b) The results of observing student activities; (c) Measurement of student learning outcomes.

The following are the results of observations during social studies learning in Grade 4 SDN 16 Paguyaman, Boalemo Regency by applying the Joyful Learning learning method.

\section{Educator Activities}

Based on the results of observations on the activities of educators, it is obtained data that educators have carried out all the aspects observed, although there are still some aspects that have not been carried out optimally. To see a comparison of the activities of educators when learning cycle I and cycle II can be seen in the following table:

Table 1. The Average Activities of Educators in Cycle I and Cycle II

\begin{tabular}{|l|l|l|l|l|}
\hline Educator Activities & Pert1 & Pert2 & Pert3 & Average \\
\hline
\end{tabular}




\begin{tabular}{|r|c|c|c|c|}
\hline CycleI & $64,58 \%$ & $73,95 \%$ & 77,08 & $\mathbf{7 1 , 8 7 \%}$ \\
\hline CycleII & $82,29 \%$ & $89,58 \%$ & $97,91 \%$ & $\mathbf{8 8 , 1 9 \%}$ \\
\hline
\end{tabular}

The increase in the average activity of educators in cycles I and II using the Joyful Learning method can be seen in the following bar chart:

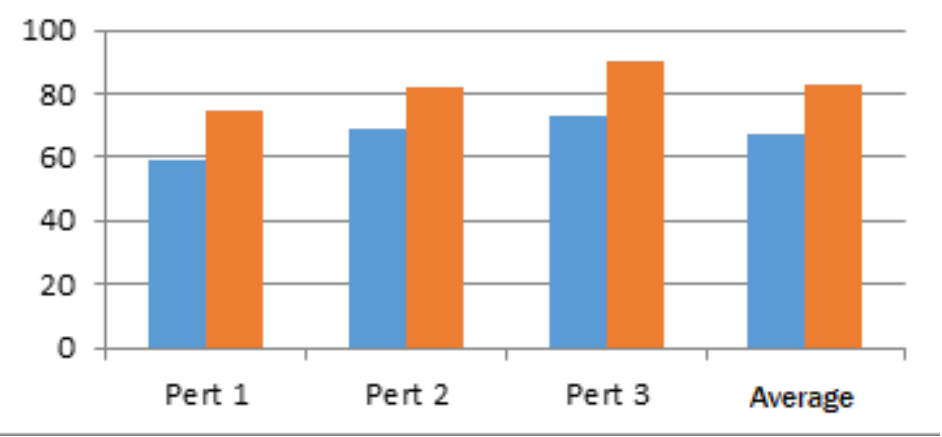

Figure 1. Picture of Increase in Average Activity of Educators in Cycles I and II

Based on the bar chart above, it is clear that there are differences in each action in the activities of educators during learning, where in the first cycle the percentage obtained was $64.58 \%$, the second meeting was $73.95 \%$, and the third meeting was $77.08 \%$, with an average score the percentage of Cycle I $73.60 \%$.

While in the second cycle the percentage obtained at the first meeting was $82.29 \%$, the second meeting was $89.58 \%$ and the third meeting was $97.91 . \%$ with an average percentage in the second cycle $88.19 \%$. With the acquisition of the average percentage in cycles I and II, it can be seen that there is an increase in the activities carried out by educators during the implementation of learning, the increase from cycle I to cycle II is around $14.59 \%$.

\section{Student Learning Activities}

The results of the study on the average percentage of students' learning activities in social studies learning activities for Class IV SDN 16 Paguyaman, Boalemo Regency using the Joyful Learning method increased in each cycle. This can be seen in table 27 below:

Table 2. Average Student Activities in Cycles I and II

\begin{tabular}{|c|c|c|c|c|}
\hline Student Activities & Pert 1 & Pert 2 & Pert 3 & Average \\
\hline Cycle I & $61,25 \%$ & $71,25 \%$ & $77,5 \%$ & $\mathbf{7 1 , 2 5 \%}$ \\
\hline Cycle II & 81,25 & $83,75 \%$ & $93,75 \%$ & $\mathbf{8 5 , 0 0 \%}$ \\
\hline
\end{tabular}

To be clearer on the increase in the average learning activity of students in cycles I and II using the Joyful Learning method, it can be seen in Figure 3 below:

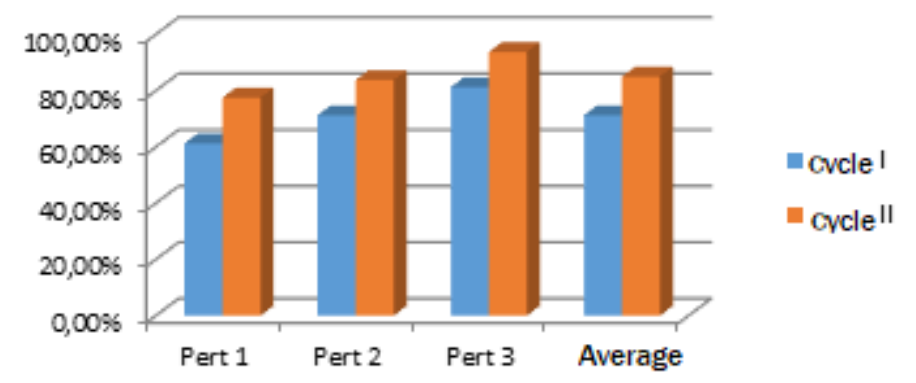

Figure 2. Increase in Average Activity of Learners Cycles I and II 
According to the data obtained, each action on students' learning activities during learning was assessed through each indicator/descriptor, in this study there were 8 student indicators assessed during the learning process, namely as follows: (1) Preparation Before Learning Activities; (a) Students answer greetings, then pray; (b) Students sit in their respective places. (2) Activities at the Beginning of Learning Activities; (a) Students sing songs from Sabang to Merauke; (b) Answering the teacher's questions about prior knowledge; (c) Students listen and pay attention to the information given by the teacher, then answer questions by playing guessing words with the discussion group. (3) Student activities when given questions/problems; (a) Learners listen to learning information; (b) Actively ask if something is not understood; (c) Students prepare media/books requested by educators. (4) Student Activities in groups. Enthusiastic students in each group when learning activities take place. (5) Student activities in drawing conclusions from LKPD problems; (a) Students work together in groups to conclude experimental activities in completing LKPD, discuss and present the results of group discussions; (b) Students enthusiastically ask and respond to the results of group presentations. (6) Student Activities in the application of learning; (a) Enthusiastic students do the teacher's orders; (b) the enthusiasm of students in each group to answer the teacher's questions; (c) Students prepare representatives from each group to be word guessing guides. (7) Student activities through the Joyful learning method; (a) Enthusiastic and competitive in experimenting with the Joyful Learning method; (b) Enthusiastic students compete in games with the Joyful learning method; (c) Students help each other in experimenting with the Joyful Learning method to complete LKPD. (8) Student activities through the Joyful learning method; (a) Record information about the material to be studied at the next meeting; (b) Pray together.

Of the eight indicators mentioned above, there are twenty aspects in total, then on the observation sheet in the research each aspect is given a value in each cycle, then the value of each cycle is totaled. Referring to the bar chart above, the learning activities of students in each cycle can be described as follows:

Based on the bar chart above in the first cycle the average percentage of student learning activities after using the Joyful Learning learning method obtained is $71.25 \%$, in Cycle II the average percentage is $85.00 \%$. seen that there is an increase in student learning activities during the implementation of learning, where the increase is quite significant by $13.75 \%$. Thus, the application of the Joyful Learning method is said to be successful.

\section{Student Learning Outcomes}

Learners are classically subjected to the action of obtaining a minimum completeness criterion value (KKM) $75 \%$, and a minimum percentage of $80 \%$ completeness. The results of the research show that the acquisition of social studies learning outcomes of students after using the Joyful Learning learning method in cycles I and II can be seen in table 28 below:

Table 3. Average Student Learning Outcomes

\begin{tabular}{|l|c|c|c|}
\hline \multirow{2}{*}{ No } & \multirow{2}{*}{ Indicator } & \multicolumn{2}{|c|}{ Test Scores } \\
\cline { 3 - 4 } & Highest Value & Cycle I & Cycle II \\
\hline 1 & Lowest Value & 88 & 100 \\
\hline 2 & Average & 70.47 & 50 \\
\hline 3 & Done & 13 & 80.23 \\
\hline 4 & Not Complete & 18 & 17 \\
\hline 5 & Average Percentage & $\mathbf{6 1 , 9 1}$ & $\mathbf{8 0 , 9 5}$ \\
\hline 6 &
\end{tabular}

The following are the results of increasing student learning, which can be seen in the diagram, to find out the results of increasing student learning after using the Joyful Learning method. 


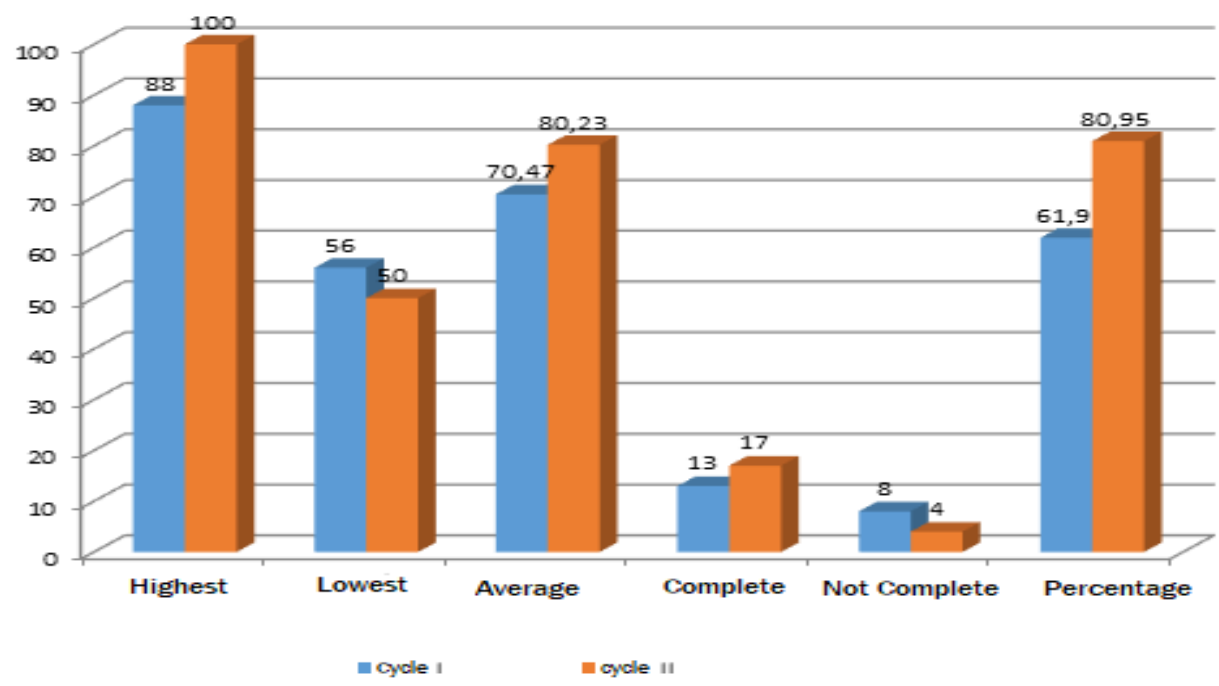

Figure 4. Average Improvement in Learning Outcomes in Cycles I and II

Based on the diagram above, the level of completeness of student learning outcomes in the first cycle is known to be an average value of $72.52 \%$ with a completeness level of $61.91 \%$. while in the second cycle it is known that the average value is 80.47 with a level of completeness of $80.95 \%$. This result is able to achieve the minimum standard of $80 \%$ that has been set and so the target for learning outcomes that is desired is more than the KKM standard.

The results of the research above indicate that student learning outcomes in social studies subjects through the Joyful Learning method have increased, this happens because educators are focused and optimal in applying the Joyful Learning learning method in learning by using the right steps. Thus, this study can prove that the Joyful Learning method can increase the activities and learning outcomes of students in social studies subjects in Class IV SDN 16 Paguyaman, Boalemo Regency.

\section{Conclusion}

Based on the results of the Class Action Research (CAR) and the discussion that has been described, it can be concluded that the implementation of learning using the Joyful Learning method can improve the results of activities and student learning outcomes in social studies subjects for class IV SD Negeri 16 Paguyaman, Boalemo Regency. This can be seen from the results of observations of student learning activities and student learning outcomes.

In the learning activities of the students in the first cycle, the average percentage was $71.25 \%$ and in the second cycle the average was $85.00 \%$, with an increase of $13.75 \%$. Similarly, the learning outcomes of students produced with the average percentage value of students in the first cycle of $72.52 \%$ with a mastery percentage of $61.91 \%$, while the average percentage value of students in the second cycle experienced an increase of 80.47 with a mastery percentage of $80.95 \%$.

\section{References}

Ardiyanti, S., Qurbaniah, M., \& Muldayanti, N. D. (2021). Joyful Learning Model: Improving Higher Order Thinking Skill and Students' Learning Motivation at Senior High School. Proceedings of KOBI 2nd International Confer, 1, 33-40.

Asmani, J. M. M. (2017). Tips aplikasi pakem (nd ed). Jogjakarta: Diva Press.

Azmin, N. H. (2016). Effect of the Jigsaw-Based Cooperative Learning Method on Student Performance in the General Certificate of Education Advanced-Level Psychology: An Exploratory Brunei Case Study. International Education Studies, 9(1), 91-106. 
Djamarah, (2010). Guru dan Anak Didik dalam Interaksi Edukatif, Jakarta: Rineka Cipta.

Hasib, M., Yassi, A. H., \& Nasmilah, N. (2021). Synchronizing Students Learning Styles in Promoting Learners' Grammatical Knowledge; a Cultural Dimensions Study. International Journal of Multicultural and Multireligious Understanding, 8(2), 264272.

Husamah, H. Pantiwati, Y.P. Restian, A.R. Sumarsono, P.S. (2018). Belajar dan pembelajaran. Malang: Universitas muhammadiyah malang.

Salirawati, D. (2018). Smart Teaching: Solusi Menjadi Guru Profesional. Bumi Aksara.

Saragih, S. (2016). The profile of communication mathematics and students' motivation by joyful learning-based learning context Malay culture. Journal of Education, Society and Behavioural Science, 1-16.

Shadiq, (2011). Rahasia Mengajar dengan Kreatif, Inspiratif, dan Cerdas. Jakarta: Ilagaligo publisher.

Siska, (2016). Konsep Dasar IPS Untuk SD/MI. Yogyakarta: Garudhawaca.

Sudjana, (2011). Dasar-Dasar Proses Belajar Mengajar. Bandung: Sinar Baru Aligensindo.

Sudjana, (2016). Penilaian Hasil Proses Belajar Mengajar. Bandung: Rosdakarya.

Susanto, (2014). Pengembangan Pembelajaran IPS di Sekolah Dasar. Jakarta: Kencana.

Yudha, (2018). Motivasi Berprestasi \& Disiplin Peserta Didik Serta Hubungannya dengan Hasil Belajar. Kalimantan Barat: Yudha English 